\title{
Innate Immunity in Hepatitis C Virus Infection
}

\author{
Johannes Schwerk, Amina Negash, Ram Savan, and Michael Gale, Jr. \\ Center for Innate Immunity and Immune Disease, Department of Immunology, University of Washington \\ School of Medicine, Seattle, Washington 98109, USA \\ Correspondence: mgale@uw.edu
}

\begin{abstract}
Activation and viral control of the innate immune response are hallmarks of hepatitis $C$ virus (HCV) infection and are major determinants of spontaneous clearance or progression to chronic infection and liver disease. In this review, we provide a contemporary overview of how HCV is sensed by the host cell to trigger innate immune activation and the mechanisms deployed by the virus to evade this response. Type I and III interferons (IFNs) are crucial mediators of antiviral innate immunity against $\mathrm{HCV}$, and we specifically highlight the importance of IFN- $\lambda$ host genetics for the outcome of HCV infection. Last, we focus on the proinflammatory responses elicited by HCV infection and describe our current understanding of how interleukin (IL)-1 $\beta$ signaling and cross talk between the IL-1 $\beta$ and IFN signaling pathways lead to sustained inflammation and increased risk of liver pathology.
\end{abstract}

epatitis C virus (HCV) typically mediates persistent infection unless fully interrupted by direct-acting antiviral (DAA) therapy (Smolders et al. 2019). Viral persistence is associated with chronic inflammatory liver disease such as fibrosis and liver cancer (Wang et al. 2020). Innate immune regulation and the hepatic inflammatory responses are major features of persistent $\mathrm{HCV}$ infection that underlie chronic hepatitis and liver disease. In this review, we provide a contemporary and comprehensive overview of these processes in the pathophysiology of HCV infection.

\section{HEPATIC INNATE IMMUNITY}

The innate immune response represents our first line of defense against microbial infection.
During a virus infection, innate immunity is triggered within the infected cell when specific pathogen recognition receptors (PRRs) of the host cell recognize and bind to non-selfmacromolecular products of an invading virus termed pathogen-associated molecular patterns (PAMPs). Viral nucleic acid represents a major PAMP of non-self-recognition by PRRs including retinoic acid-inducible gene-I (RIG-I)like receptors (RLRs) and Toll-like receptors (TLRs), as well as other PRRs that drive innate immunity and inflammation (Chow et al. 2018; Streicher and Jouvenet 2019). In particular, the RLR pathway plays a prominent role in sensing of HCV through the actions of RIG-I. RIG-I is the charter member of the RLR family of proteins that includes RIG-I, melanoma differentiation antigen 5 (MDA5), and Laboratory of Ge-

Editors: Arash Grakoui, Jean-Michel Pawlotsky, and Glenn Randall

Additional Perspectives on Hepatitis C Viruses: The Story of a Scientific and Therapeutic Revolution available at www.perspectivesinmedicine.org

Copyright (C) 2021 Cold Spring Harbor Laboratory Press; all rights reserved; doi: 10.1101/cshperspect.a036988

Cite this article as Cold Spring Harb Perspect Med 2021;11:a036988 
J. Schwerk et al.

netics and Physiology 2 (LGP2). The RLRs are cytosolic RNA helicases (Yoneyama et al. 2004; Chow et al. 2018). RIG-I and MDA5 harbor tandem caspase activation and recruitment domains (CARDs) that facilitate signaling through CARD-CARD interaction with the signaling adaptor protein, mitochondrial antiviral-signaling protein (MAVS) (Loo et al. 2006). LGP2 lacks CARDs and is thought to function as a regulator of the RLR signaling pathway (Yo- neyama et al. 2004). During acute HCV infection, RIG-I recognizes viral RNA as non-self, serving to trigger downstream signaling through MAVS leading to innate immune activation (Fig. 1).

\section{THE RLR PATHWAY}

RIG-I mediates the recognition of RNA that has free and exposed $5^{\prime}$ triphosphate with double-

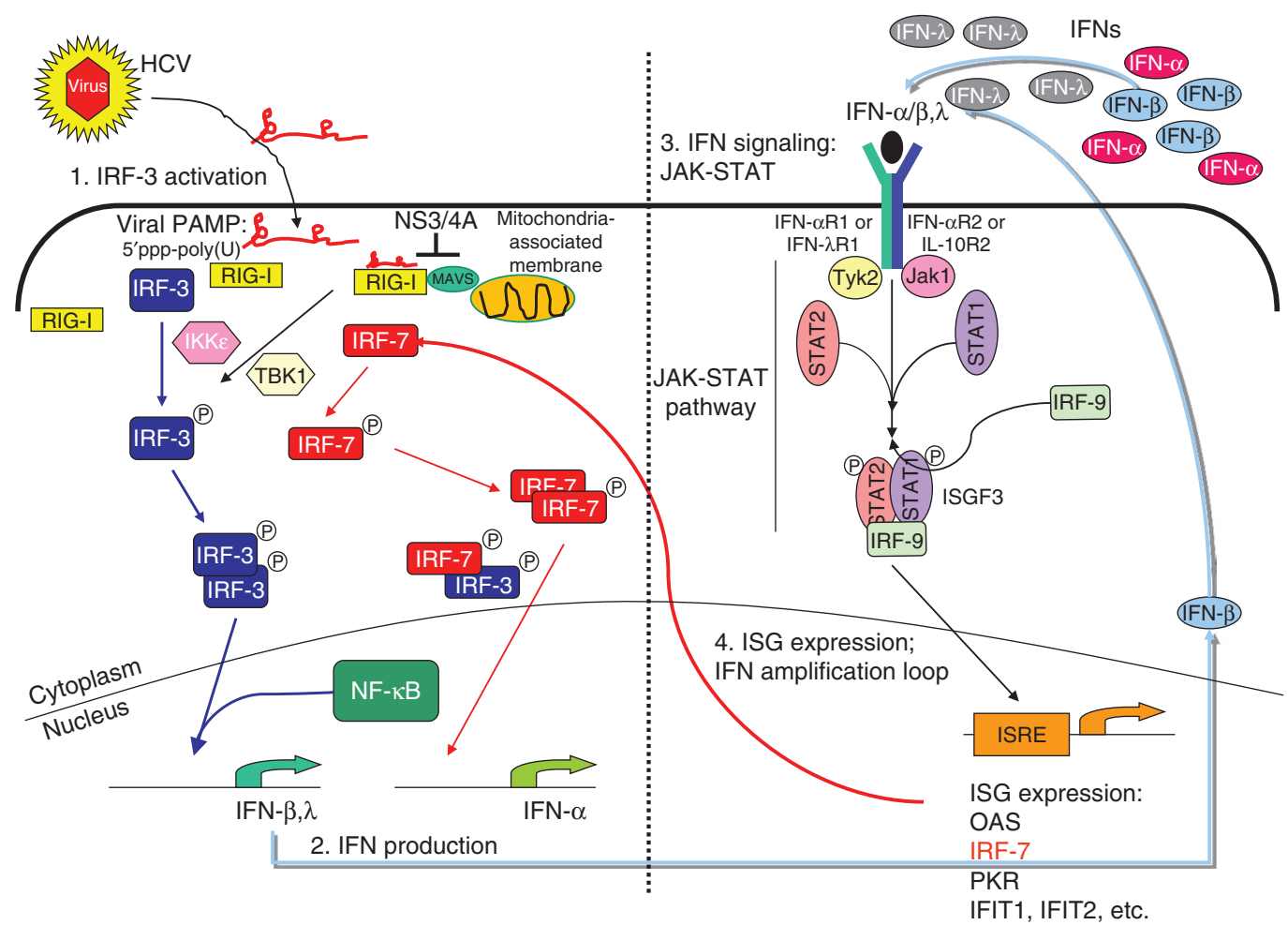

Figure 1. Sensing and innate immune response to hepatitis $\mathrm{C}$ virus (HCV). During acute HCV infection in the hepatocyte, the cytosolic RIG-I-like receptor (RLR), retinoic acid-inducible gene-I (RIG-I), recognizes $5^{\prime}$-triphosphate double-stranded RNA (dsRNA) motifs and/or polyuridine ( poly(U)) motifs within HCV RNA. Upon pathogen-associated molecular patterns (PAMPs) binding, RIG-I translocates to the mitochondria-associated membranes (MAMs) where it interacts with the adaptor molecule mitochondrial antiviral-signaling protein (MAVS). Interaction of RIG-I with MAVS at the MAM signaling platform recruits and activates the downstream transcription factors IRF-3 and NF- $\kappa \mathrm{B}$, resulting in the induction of antiviral and immune modulatory type I (interferon $[\mathrm{IFN}]-\alpha / \beta$ ) and III (IFN- $\lambda$ ) IFNs. Secreted IFNs bind their cognate receptors IFN- $\alpha \mathrm{R}$ and IFN- $\lambda$ R on the cell surface. This autocrine and paracrine IFN signaling engages the JAK/STAT signaling cascade downstream of the IFN receptor and mediates activation and nuclear translocation of the trimeric ISGF3 transcription factor complex, which binds to IFN-stimulated response elements (ISREs) in the promoter regions and induces expression of hundreds of IFN-stimulated genes (ISGs) to establish an antiviral state. The viral NS3/4A protease accumulates in the infected cell and targets and cleaves MAVS, releasing it from the MAM and thus inactivating the RLR pathway. This process allows HCV to evade intracellular innate immunity to mediate persistent viral replication and chronic infection. 
stranded RNA (dsRNA) and/or polyuridine $(\operatorname{poly}(\mathrm{U}))$-rich motifs. Together, these features of HCV RNA mark it as non-self and facilitate recognition and direct binding by RIG-I to the viral RNA (Foy et al. 2005; Sumpter et al. 2005). RIG-I specifically recognizes the 5'ppp of the viral genome RNA in combination with the $3^{\prime}$ untranslated region (UTR) poly(U)-rich motif (Saito et al. 2008). During viral RNA replication dsRNA structures within the $5^{\prime}$ end of the HCV genome mediate a "kissing loop" interaction with dsRNA structures in the $3^{\prime}$ end of the genome, which brings the $5^{\prime}$ ppp into close proximity to the poly $(\mathrm{U})$ motif, comprising the PAMP that is recognized by RIG-I (Friebe et al. 2005; Schnell et al. 2012). Upon PAMP binding, RIG-I hydrolyzes ATP and undergoes a major conformation change that places it in a "signaling-on" conformation, thus allowing RIG-I to mediate cofactor interactions and formation of a RIG-I-translocon that chaperones RIG-I interaction with MAVS on mitochondria-associated membranes (MAMs). The MAM acts as an innate immune signaling platform that allows signaling molecules interaction that directs the downstream activation of interferon (IFN) regulatory factor-3 (IRF-3) and NF- $\mathrm{KB}$. IRF-3 induces the expression of many target genes including antiviral and immune modulatory genes, whereas $\mathrm{NF}-\mathrm{\kappa B}$ directs the expression of a variety of inflammatory mediators including interleukin $1 \beta$ (IL-1 $\beta$ ), as discussed below. IRF-3 and NF$\kappa \mathrm{B}$ together participate in the induction of type I and III IFN expression (described below). IFNs are major antiviral factors secreted from the infected cell to signal locally and systemically through binding the cognate IFN receptor and driving signaling that induces hundreds of IFN-stimulated genes (ISGs). ISG products have antiviral, inflammatory, and immunemodulatory functions that together restrict virus replication and spread and serve to polarize the adaptive immune response for effector actions against infection (Schoggins 2019). Problematically, $\mathrm{HCV}$ targets and inactivates the RLR pathway early during acute infection, thus evading intracellular hepatic innate immune defenses.

\section{INTRACELLULAR INNATE IMMUNE EVASION BY HCV}

$\mathrm{HCV}$ replication is mediated through the actions of the viral nonstructural (NS) proteins and host cofactors (Tabata et al. 2020). The viral NS proteins include the NS3/4A serine protease that imparts processing of the viral polyprotein for liberation of NS proteins to establish the viral replicase (Bartenschlager 1999). Importantly, NS3/4A also is shown to target and cleave MAVS in vitro in HCV infection models and in vivo in the liver of chronically HCVinfected patients (Levitzki et al. 1991). NS3/4A cleavage of MAVS releases it from intracellular membranes. MAVS must be anchored on the MAM or outer mitochondria membrane for RLR signaling to occur. Thus, once MAVS is cleaved by the HCV NS3/4A protease, the RLR pathway is rendered inactive within the infected cell, allowing $\mathrm{HCV}$ to replicate and spread through the liver (Lau et al. 2008). HCV mediates cell-to-cell spread through tight junction molecules that serve as receptors for the virus (Zeisel et al. 2018; Gerold et al. 2020). When initiating infection in neighboring hepatocytes, the RLR pathway is again activated via RIG-I sensing of HCV PAMP, leading to IFN expression and secretion. As HCV continuously spreads from cell to cell, this process drives de novo IFN production and ISG expression, placing the liver in a continuous stage of innate immune stimulation and activation (Wilkins et al. 2013). Although RLR signaling is then effectively shut off in the infected cell from NS3/ 4A-mediated cleavage of MAVS, the spread of $\mathrm{HCV}$ through the liver continues to drive this state of hepatic innate immune activation. HCV has also been shown to be sensed by TLR3 at least in vitro wherein TLR3 signaling can drive innate immune activation. In vitro studies show that the viral NS3/4A protease can target and cleave the cellular TRIF protein, an essential cofactor of TLR3 signaling (Li et al. 2005; Wang et al. 2009). This process abrogates the TLR3 pathway concomitant with disruption of RLR signaling by the NS3/4A protease (Ferreon et al. 2005). However, the relevance of TLR3 regulation by HCV has not been demonstrated 
in vivo, and it is not known whether TLR3 actually senses HCV PAMPs to direct innate immune activation in the infected human liver.

\section{INTERFERONS IN HCV INFECTION}

The continuous hepatic innate immune activation during $\mathrm{HCV}$ infection plays an important role in recruiting immune cells to the liver, including myeloid cells and lymphocytes (Lau et al. 2013). Dendritic cell (DC) recruitment to the HCV liver provides a source of IFN wherein HCV RNA can be encountered by infiltrating DCs through exosomes containing the HCV RNA that are shed by infected hepatocytes (Dreux et al. 2012). This process results in DC activation and the production and secretion of IFN into the hepatic environment (Longatti et al. 2015). Moreover, the IFN production driven by acute RLR signaling serves to activate resident hepatic cells including stellate cells, liver macrophages, or Kupffer cells (KCs), endothelial cells and others (Lin et al. 2014). Indeed, transcriptional profiling studies of liver gene expression in HCV patients show a remarkable and complex gene expression signature marked by ISGs, inflammatory genes, immune regulatory genes, and metabolic genes that underlie the development of tissue fibrosis and liver disease (Helbig et al. 2005). ISGs often dominate the gene expression signature of the chronic HCV liver owing to the ongoing production of IFN as the virus triggers RIG-I signaling during the spread of infection and from the actions of infiltrating myeloid cells that produce IFN (Lau et al. $2008,2013)$. Both type I (IFN- $\alpha / \beta)$ and type III (IFN- $\lambda$ ) IFNs are produced by these cells in $\mathrm{HCV}$-infected liver. IFNs act to bind to their respective cognate receptors-IFN- $\alpha \mathrm{R}$ and IFN- $\lambda \mathrm{R}$ - on the cell surface. Engagement of the receptors by IFN activates the JAK/STAT signaling cascade downstream of the receptor, which results in formation and nuclear translocation of the heterotrimeric transcription factor complex ISGF3 consisting of STAT1, STAT2, and IRF-9. ISGF3 binds to promoter regions of numerous ISGs (Fig. 1). Only a handful of ISGs have been functionally described as antiviral effector molecules, such as IRF1, OAS1, IFITM1,
IFI44L, OASL, and RNaseL, some of which act directly as antiviral against HCV and other viruses (Schoggins et al. 2011; Metz et al. 2013). For years, the standard of care for all HCV patients prior to the introduction of DAA, which are small-molecule antiviral drugs against $\mathrm{HCV}$, was a combination therapy of pegylated IFN- $\alpha$ with ribavirin.

\section{SIMILARITIES AND DISTINCT ANTIVIRAL PROPERTIES OF TYPES I AND III INTERFERONS}

Although type I IFNs were first described more than six decades ago (Isaacs and Lindenmann 1957), it was not until 2003 that the family of type III IFNs was discovered (Kotenko et al. 2003; Sheppard et al. 2003). One of the major differences between the two IFN families is the tissue restriction of their cognate receptors. The heterodimeric IFN- $\alpha \mathrm{R}$, consisting of the IFN$\alpha \mathrm{R} 1$ and IFN- $\alpha \mathrm{R} 2$ receptor subunits, is ubiquitously expressed. In contrast, expression of the IFN- $\lambda R$, composed of the IFN- $\lambda$ R 1 and IL-10R 2 subunits, is restricted to cells of the mucosal epithelium and hepatocytes to provide antiviral protection at these sites (Sommereyns et al. 2008). Recent studies have shown that certain immune cells such as neutrophils and DCs are responsive to IFN- $\lambda$ (Broggi et al. 2017; Hemann et al. 2019).

Type I and III IFNs induce the expression of a mostly overlapping set of ISGs (Zhou et al. 2007; Ank et al. 2008). Nevertheless, differences in gene induction patterns between the two IFN families lead to distinct functional consequences (Marcello et al. 2006; Jilg et al. 2014; Hong et al. 2016; Forero et al. 2019). The temporal pattern of ISG expression upon type III IFN sensing is delayed and sustained, whereas type I IFN elicits an early but transient ISG induction (Fig. 2; Marcello et al. 2006; Jilg et al. 2014; Forero et al. 2019). An important distinction between the two IFN families is that IFN- $\lambda$ does not promote inflammatory responses that type I IFN evokes at epithelial barrier surfaces (Davidson et al. 2016; Galani et al. 2017). This distinct response is attributed to the decreased induction of the transcription factor IRF-1 through limited 

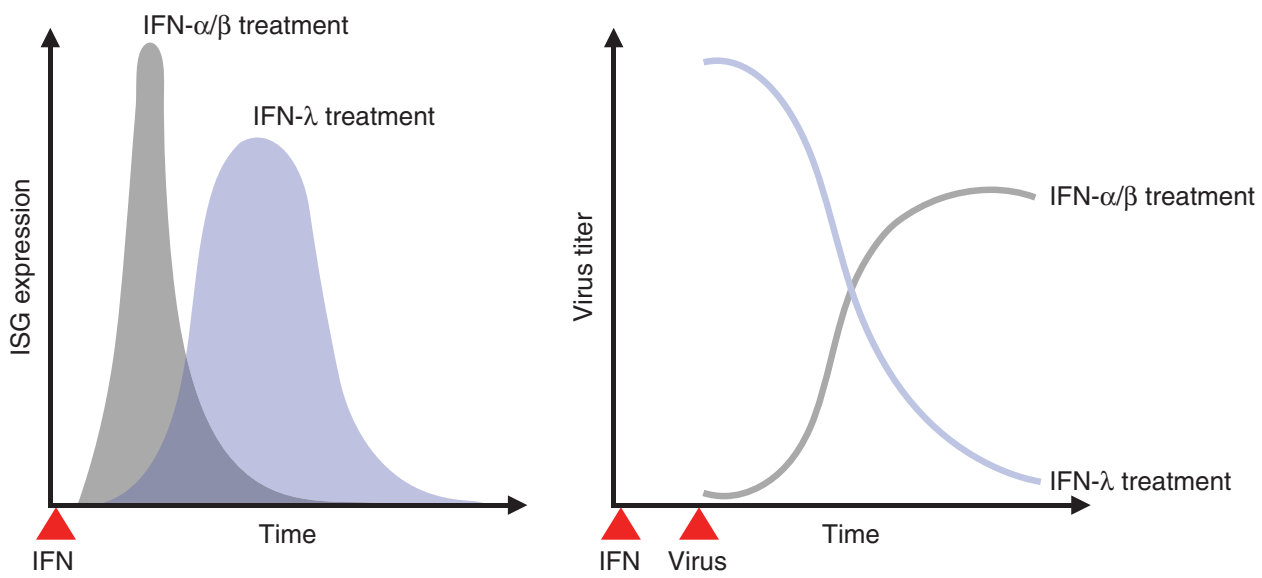

Figure 2. Differential interferon (IFN)-stimulated gene (ISG) expression kinetics of type I and type III IFN. Type I $($ IFN- $\alpha / \beta)$ and type III (IFN- $\lambda$ ) IFNs confer differential ISG expression kinetics in epithelial cells upon engagement of their respective receptors. The response induced by type I IFN is immediate and short-lived. In contrast, type III IFN-induced ISG expression is delayed, but sustained. This division of labor between type I and type III IFN results in optimal establishment of an antiviral state.

formation of STAT1 homodimers by IFN- $\lambda$ and a simultaneously increased induction of factors associated with tissue repair (Fig. 3; Forero et al. 2019). These unique properties of IFN- $\lambda$ have long been considered a major advantage over pegylated IFN- $\alpha$, which is routinely used in combination with ribavirin in the clinics to treat chronic HCV infection, as it would act on a more restricted pool of cell types (including hepatocytes) and thereby reduce the adverse side effects caused by pegylated IFN- $\alpha$ treatment. The potential of IFN- $\lambda$ as a far more efficient alternative for treatment of chronic HCV infection over type I IFN therapy has been further highlighted by the advent of genome-wide association studies showing strong correlation between singlenucleotide polymorphisms (SNPs) in the IFNL locus and outcome of HCV infection (Ge et al. 2009; Suppiah et al. 2009; Tanaka et al. 2009; Thomas et al. 2009; Rauch et al. 2010).

\section{IMPORTANCE OF INTERFERON- $\lambda$ GENETICS IN HCV INFECTION}

Soon after its initial discovery, the antiviral potential of type III IFN was explored and showed similar potential as type I IFN (Dumoutier et al. 2004; Ank et al. 2006). Several studies have shown that SNPs in the IFNL locus strongly associate with spontaneous and type I IFN therapy-induced HCV clearance. Several independent $\mathrm{HCV}$ infection cohorts have replicated the genetic associations with IFNL SNPs (Ge et al. 2009; Suppiah et al. 2009; Tanaka et al. 2009; Thomas et al. 2009; Rauch et al. 2010; Prokunina-Olsson et al. 2013). Although the importance of individual IFNL SNPs as predictors of HCV susceptibility and clearance of infection is contentious, there is a uniform consensus that SNPs in the IFNL locus are the best predictors for outcome of HCV infection. Because associations of IFNL SNPs with HCV susceptibility are strong, many groups including ours, have been in the hunt to identify the functional SNP that affects HCV clearance.

Three SNPs in the IFNL locus seem to exhibit features of functionality (Fig. 4). The most obvious candidate SNP (rs368234815) in the IFNL4 gene is a dinucleotide variant that confers the protein-coding potential of IFNL4 (Bibert et al. 2013; Prokunina-Olsson et al. 2013; Aka et al. 2014). Interestingly, contrary to the conventional protective antiviral function of IFNs, the SNP variant predicting to encode functional IFN- $\lambda 4$ protein, associates with increased risk of $\mathrm{HCV}$ persistence, whereas 
J. Schwerk et al.

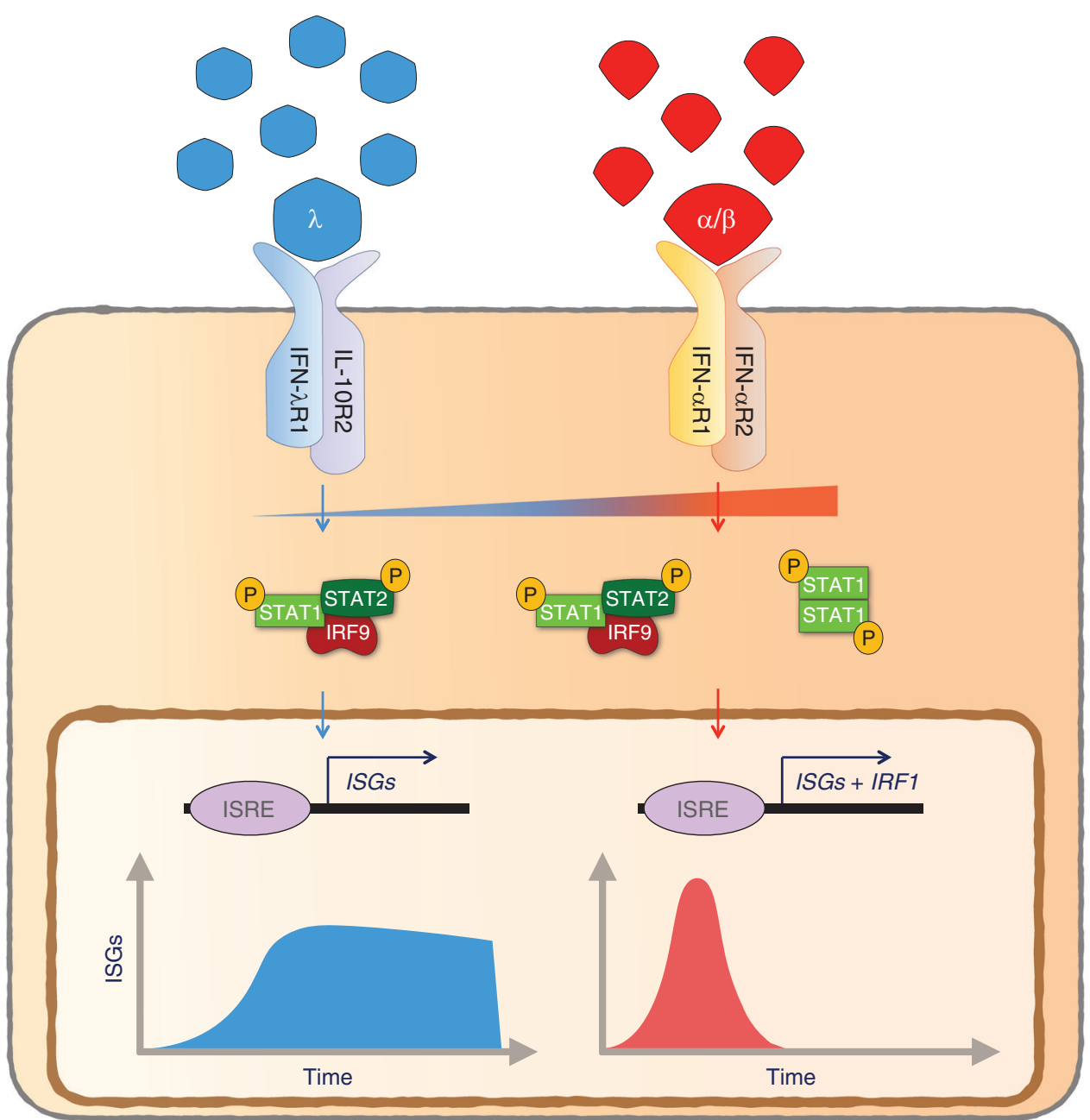

Figure 3. Type I, but not type III interferon (IFN), promotes inflammatory responses at the site of infection. The proinflammatory gene signature induced by type I IFN $(\operatorname{IFN}-\alpha / \beta)$ is caused by increased induction of IRF1 through type I IFN-mediated STAT1 homodimer formation. In contrast, lower abundance of surface IFN- $\lambda \mathrm{R}$ expression leads to insufficient activation of STAT1 homodimer formation required for induction of IRF1 and downstream inflammatory genes.

patients with the noncoding IFNL4 SNP variant clear the virus (Aka et al. 2014; Meissner et al. 2014; Lu et al. 2015a,b; O'Brien et al. 2015; Peiffer et al. 2016). Another SNP in IFNL4 (rs117648444) causes a P70S substitution that leads to decreased activity of IFN- $\lambda 4$ protein and correlates with increased clearance of $\mathrm{HCV}$ infection in patients (Prokunina-Olsson et al. 2013; Terczynska-Dyla et al. 2014). This puzzling observation, combined with the inability to detect IFN- $\lambda 4$ protein in liver biopsies of
$\mathrm{HCV}$ patients, complicates the functional significance of IFNL4 in HCV infection and clearance. Moreover, as IFNs are known to clear HCV infection, the paradoxical activity of IFNL4 is in stark contrast to biological studies showing that recombinant IFN- $\lambda 4$ protein has a similar antiviral activity to IFN- $\lambda 3$ (Hamming et al. 2013; Hong et al. 2016). However, compared to IFNB and IFNL1-3 mRNAs, the induction of fulllength IFNL4 mRNA is barely detectable. Furthermore, unlike other IFNL genes, IFNL4 is 


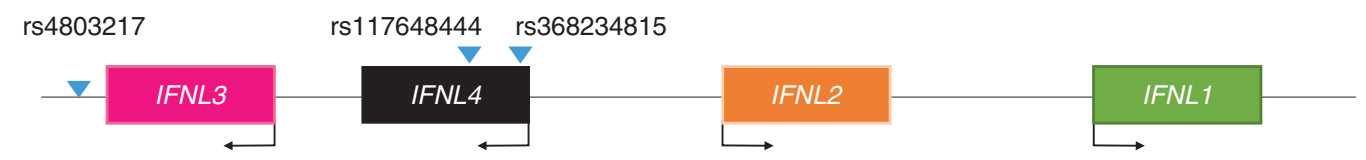

Figure 4. Functional single-nucleotide polymorphisms (SNPs) in the human IFNL locus. Several SNPs in the human IFNL locus have been shown to be functional. The dinucleotide variant rs368234815 in the IFNL4 gene confers protein-coding potential and associates with decreased clearance of hepatitis $\mathrm{C}$ virus (HCV) infection. The P70S substitution (rs117648444) leads to decreased activity of recombinant interferon (IFN)- $\lambda 4$, which associates with improved HCV infection outcome. The SNP rs4803217 located in the $3^{\prime}$ untranslated region (UTR) of the IFNL3 gene affects stability of IFNL3 mRNA through AU-rich elements (AREs) and microRNA (miRNA) binding sites.

alternatively spliced to produce several nonfunctional mRNA isoforms and intron-retained isoforms that probably undergo nonsense-mediated decay (Hong et al. 2016). Finally, IFNL4 mRNA is not efficiently loaded onto polyribosomes for translation, because of inefficient polyadenylation of the mRNA (Hong et al. 2016). Based on these observations, one hypothesis is that the host has adopted multiple measures to suppress IFN- $\lambda 4$ protein expression. Our study provides mechanistic evidence that humans do not express functional IFN- $\lambda 4$ protein irrespective of the IFNL4 SNP genotype, suggesting that the antiviral activity against HCV is mediated through IFN- $\lambda 1-3$ and type I IFN. Because the IFNL4 genotype predicted to produce functional IFN- $\lambda 4$ protein is in strong linkage with the less favorable IFNL3 genotypes at rs12979860 and rs4803217 (Lu et al. 2015b), it is possible that the association of IFNL4 genotype with HCV persistence is based on an indirect effect of less favorable IFNL3 genotypes. Nevertheless, the SNPs in IFNL4 are strong predictors for HCV clearance or persistence in patients and further research efforts are required to identify the functional mechanism(s) behind IFNL4 SNP genotype and outcome of HCV infection (Prokunina-Olsson et al. 2013).

The other SNP in the IFNL locus that was predicted to have a functional consequence on HCV infection is in the $3^{\prime}$ UTR of IFNL3 mRNA (Fig. 4). We found that the SNP rs4803217 influenced the stability and turnover of IFNL3 mRNA through AU-rich elements (AREs) and microRNA (miRNA) binding sites encoded in the IFNL3 3' UTR (McFarland et al. 2014). HCV-induced miRNA expression such as miR-208b and miR-499a-5p target miRNA binding sites in the IFNL3 $3^{\prime}$ UTR, thereby mediating instability through ARE-mediated decay. As the SNP rs4803217 lies in the miRNA seed region, the HCV-induced miRNAs target and repress the risk allele of IFNL3 (T/T) but not the protective allele $(\mathrm{G} / \mathrm{G})$. Specific inhibition of HCV-induced miR-208b and miR-499a-5p led to a significant decrease of HCV replication (McFarland et al. 2014). Furthermore, HCV-induced type I IFN amplifies miR-208b and miR499a-5p expression in hepatocytes. In patients with the unfavorable IFNL3 (T/T) genotype, this would further suppress IFN- $\lambda 3$ protein expression, making this genotype particularly unfavorable during type I IFN therapy. By contrast, patients with the favorable IFNL3 (G/G) genotype would escape this posttranscriptional regulation and have increased expression of IFN- $\lambda 3$. Additionally, HCV-induced miRNAs miR-208b and $\mathrm{miR}-499 \mathrm{a}-5 \mathrm{p}$ also negatively regulate expression of IFNAR1 mRNA of the type I IFN receptor subunit, thereby dampening type I IFN signaling in response to HCV infection (Jarret et al. 2016). The fact that treatment of HCV-infected hepatocytes with recombinant type I IFN led to increased expression of miR-208b and miR499a-5 than just HCV infection alone, explains why chronic HCV patients with the unfavorable IFNL3 (T/T) genotype respond poorly to type I IFN therapy.

\section{HCV-INDUCED LIVER INFLAMMATION}

Although recent advances in drug discovery and development have shifted the standard of care for HCV patients to DAAs with much success, future setbacks can be expected because of mutations in $\mathrm{HCV}$ and emergence of DAA 
resistance variants. Thus, a more detailed understanding of the inherent innate immune responses and the molecular mechanisms underlying the effect of host genetic polymorphisms to outcomes of HCV infection are essential to tailor adequate treatment strategies in the future. DAA therapy is instrumental to $\mathrm{HCV}$ cure but has not proven to facilitate the repair of a diseased liver from HCV infection. Indeed, $\mathrm{HCV}$ directs a chronic inflammatory disease that is marked by local hepatic production of IL-1 $\beta$ (Negash and Gale 2015). Although the innate immune response, as discussed above, is rapidly deployed within the liver during an infection to restrict and clear pathogens such as viruses (Akira et al. 2006; Thompson et al. 2011; Liaskou et al. 2012), liver inflammation (hepatitis) within the hepatic microenvironment during HCV infection occurs as an orchestrated and progressive event whose outcome is conferred by signaling cross talk including intercellular cross talk conferred by intrahepatic cells (Ishii and Koziel 2008; Kumar et al. 2013; Park and Rehermann 2014; Negash and Gale 2015). IL-1 $\beta$ is a key proinflammatory factor that has been implicated in HCV-induced hepatitis (Burdette et al. 2012; Negash et al. 2013; Shrivastava et al. 2013; Chattergoon et al. 2014; Farag et al. 2017; Molyvdas et al. 2018). IL-1 has diverse biological activity and is a pivotal player in immune regulation during acute and chronic viral infection (Dinarello 2002; Ichinohe et al. 2009; Rajan et al. 2011; Ramos et al. 2012). As one of the early proinflammatory cytokines produced during an infection, its production increases the production of other proinflammatory mediators, promotes the migration of leukocytes, induces growth factor production for the maturation of immune cells, and imparts immune polarization (Negash and Gale 2015).

IL-1 exists as two forms within the body, IL$1 \alpha$ and IL-1 $\beta$ (Dower et al. 1986; Sims et al. 1989). They both engage IL-1 receptor 1 (IL$1 \mathrm{R})$ to induce NF- $\kappa \mathrm{B}$ activation and drive the expression of inflammatory genes including IL1. Although IL- $1 \alpha$ is readily produced by many cell types in response to stimuli (Di Paolo and Shayakhmetov 2016), IL-1 $\beta$ production is tightly controlled at the expression, processing, and maturation stages. The inflammasome is a cytoplasmic, multiprotein-containing, and oligomerizing signaling complex that leads to the maturation and release of bioactive IL- $1 \beta$ (Martinon et al. 2002; Jin and Flavell 2010). The inflammasome complex is composed of a NOD-like receptor such as NLRP3, adaptor protein ASC, and the effector protease caspase-1. Initiation of NLRP3 inflammasome signaling is triggered by a priming step or "signal-one," which leads to the transcriptional induction of NLRP3 and IL-1 $\beta$. To promote mature and active IL- $1 \beta$ production and release, an inflammasome-activating signal called "signal-two" is required. PAMP/PRR interaction leads to signalone activation to produce immature pro-IL-1 $\beta$ protein. On the other hand, signal-two activation is triggered by diverse cellular responses, often induced by the ensuing infection, such as potassium efflux, calcium signaling, and endosomal rupture. To date, several inflammasomes are activated in response to viruses, bacteria, and particulate matters such as monosodium urate and asbestos. In particular, the well-characterized NLRP3 inflammasome has been shown to respond to diverse stimuli including viral infections such as with HCV (Rajan et al. 2011; Elliott and Sutterwala 2015).

Expression of the key inflammasome components occurs in most cell types and tissues, including the liver. The liver shows an overall low-level expression of NLRP3 mRNA, but high hepatic caspase-1 expression, the initiator caspase of NLRP3 inflammasome activation (Lech et al. 2010; Csak et al. 2011). Moreover, hepatocytes and stellate cells express inflammasome components (Masumoto et al. 2001; Anderson et al. 2004; Watanabe et al. 2009). Several studies implicated IL-1 $\beta$ in HCV-associated liver inflammation. Early studies (Tanaka et al. 2003; Wang et al. 2003) found that in HCV-infected patients a polymorphism at the $I L 1 B$ locus conferred high risk for developing HCVmediated hepatocellular carcinoma (HCC). Further studies revealed that IL-1 $\beta$ protein can be detected in sera of $\mathrm{HCV}$-infected individuals (Bortolami et al. 2008; Baranova et al. 2011; Negash et al. 2013). Gene expression profile analyses revealed that IL- $1 \beta$ expression is linked to 
$\mathrm{HCV}$-induced severe liver disease. The HCVinfected cirrhotic liver contains a high level of IL-1 $\beta$, whereas the cytokine is low or not detected in infected individuals with only mild liver disease. These in vivo findings lead to further research to characterize the signaling events of $\mathrm{HCV}$-induced IL-1 $\beta$ production as a mechanism by which HCV-associated hepatic inflammation is established.

Although active $\mathrm{HCV}$ replication can be detected only in hepatocytes, inflammasome activation by $\mathrm{HCV}$ in hepatocytes is only weakly induced. Instead, hepatic macrophages respond robustly to $\mathrm{HCV}$ by producing IL-1 $\beta$ (Negash et al. 2013; Shrivastava et al. 2013; Chattergoon et al. 2014). Within the hepatic environment initiation of inflammatory responses within the liver is carried out by KCs (Krenkel and Tacke 2017; Li et al. 2017), liver-resident macrophages. The KCs are the chief producers of inflammatory mediators. Immunohistochemistry analysis identified that macrophages including KCs are the major producers of IL- $1 \beta$ within $\mathrm{HCV}$-infected liver as compared to healthy uninfected liver. Similarly, stimulation with HCV of various immune cell subsets such as monocytes, natural killer (NK) cells, and T cells isolated from peripheral blood revealed that only monocytes and macrophages responded to $\mathrm{HCV}$ by producing IL-1 $\beta$. HCV triggers NLRP3 inflammasome activation to induce IL$1 \beta$ release from KCs or liver-infiltrating macrophages. Macrophages were found to engulf $\mathrm{HCV}$ virions leading to sensing of $\mathrm{HCV}$ and triggering of IL- $1 \beta$ release. Induction of $I L 1 B$ mRNA and downstream production of immature of IL-1 $\beta$ protein was shown to be triggered by TLR7-mediated recognition of HCV RNA and signaling through MyD88 in macrophages (Negash et al. 2013). Two of the HCV proteins, p7 and core, have been shown to serve as NLRP3 inflammasome agonists. The HCV viroporin, p7, from different genotypes is indeed able to drive NLRP3 activation (Farag et al. 2017). A more recent report showed that the $\mathrm{HCV}$ core protein is a major virion component that is able to trigger NLRP3 inflammasome assembly and activation in macrophages (Negash et al. 2019). The HCV core protein activates the NLRP3 in- flammasome through modulation of intracellular calcium signaling pathways. IL-18 is another cytokine that belongs to the IL- 1 family and is regulated by the inflammasome pathway (Dinarello 1999; Vecchiet et al. 2005; Chattergoon et al. 2011). Like IL-1 $\beta$, IL-18 is detected in $\mathrm{HCV}$-infected individuals and remains high in chronic infection, underscoring its important role in HCV pathogenesis (Fig. 5).

IL-1 $\beta$ and IFN cross talk sustain the inflammatory response. As a major proinflammatory mediator, IL- $1 \beta$ directs a signaling cascade that induces the expression of hundreds of genes in responding cells (Negash et al. 2013; Aarreberg et al. 2018). Many of these gene products function to amplify and diversify the inflammatory response by activating and recruiting immune cells. Analysis of the gene expression profile of blood and liver from chronic HCV patients revealed a strong inflammatory signature concomitant with increased IL-1 $\beta$ levels (Negash et al. 2013; Khatun and Ray 2019). Remarkably, many ISGs were present and highly expressed in a manner linked with IL-1 $\beta$ levels. Analysis of liver tissue from these patients demonstrated the presence of type I IFN within KCs of the chronic HCV liver, the same cells that produce and respond to IL-1 $\beta$, suggesting that KCs or macrophages in particular might respond to either cytokine to program rounds of signaling by the other cytokine. In this respect, recent studies have shown that IL- $1 \beta$ signaling in macrophages, hepatocytes, and other epithelial cells leads to the release of mitochondrial DNA from the mitochondria of the responding cell. This process likely occurs through IL-1 $\beta$-mediated damage and permeabilization of mitochondria leading to accumulation of mitochondrial DNA in the cell cytoplasm. Genetic studies then showed that the cytoplasmic mitochondrial DNA is sensed by the cGAS protein leading to production of cGAMP and activation of the STING adaptor protein (Aarreberg et al. 2019). This process then leads to IRF-3 and NF- $\kappa B$ activation, thus mediating IFN production. Whereas typically IFN is produced acutely in response to PRR signaling in virus infection, the IL-1 $\beta$-driven induction of IFN during virus infection occurs later, as it is dependent on 
J. Schwerk et al.

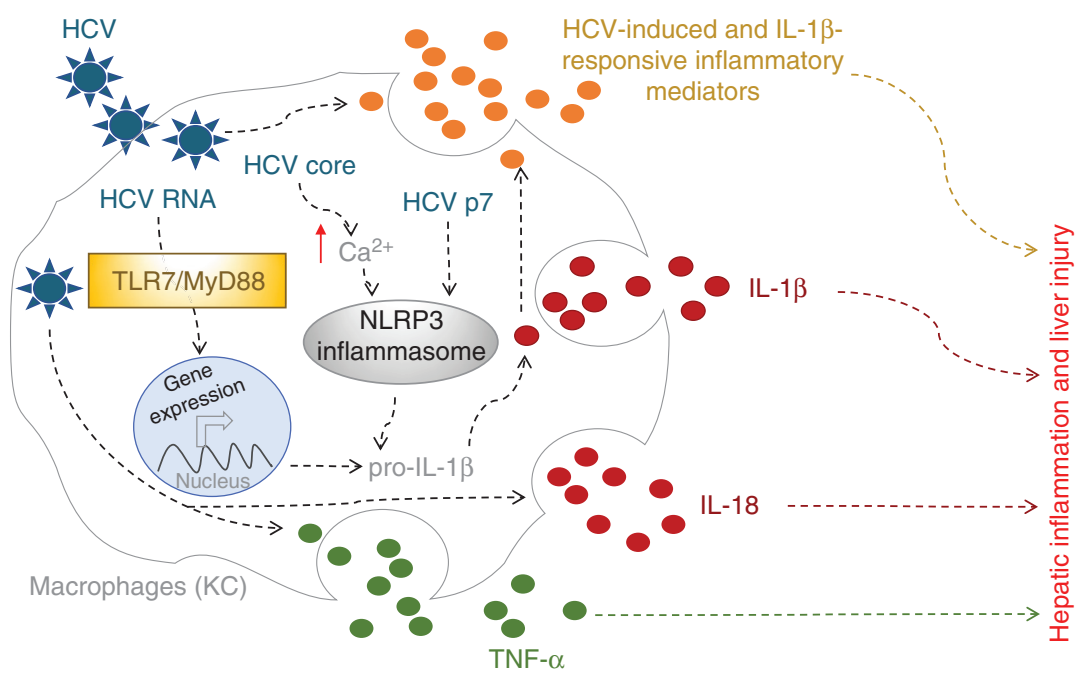

Figure 5. Hepatic inflammation during hepatitis C virus (HCV) infection. Hepatic macrophages (Kupffer cells $[\mathrm{KCs}])$ produce and secrete inflammatory mediators such as IL-1 $\beta$, IL-18, and TNF- $\alpha$ through combined activation of the endosomal TLR7/MyD88 pathway by HCV RNA and activation of the NLRP3 inflammasome by the HCV viroporin p7 and core proteins. High expression of IL-1 $\beta$ is a hallmark of HCV-infected cirrhotic liver and a key contributor to hepatic inflammation and HCV-induced liver disease.

IL-1 $\beta$ production following NLRP3 inflammasome activation (Aarreberg et al. 2018, 2019), thus establishing a cytokine cross talk circuit to amplify and extend IFN induction while mediating inflammatory signaling. When active in the HCV liver, this process contributes to continued inflammation linked with liver damage and continuous ISG expression. As a result, the liver was shown to become refractory to the actions of IFN because of obtaining a state of "innate immune tolerance" that facilitates cell survival to overcome the otherwise hepatotoxicity mediated by constitutive ISG expression and inflammatory response (Lau et al. 2013). Although innate immune tolerance is thought to protect the liver tissue from inflammatory cell death, the outcome is that the cells develop tolerance and become refractory to the antiviral actions of IFN. Indeed, analysis of liver gene expression profiles in patients with chronic $\mathrm{HCV}$ who were undergoing IFN therapy showed that the unresponsive liver failed to induce ISG expression beyond the level of expression mediated through cytokine cross talk that was ongoing (Lau et al. 2013). The process of innate immune tolerance might impart reduced efficacy to IFN therapy for treatment of $\mathrm{HCV}$ infection.

\section{FUTURE CONSIDERATIONS}

HCV infection causes an inflammatory disease of the liver. In the era of DAAs, current therapy effectively overcomes the obstacle of innate immune tolerance and nonresponse to IFN to mediate HCV cure (Sandmann et al. 2019). However, the incidence of HCV infection among high-risk groups continues to present a public health concern (Wu et al. 2019), and coinfections with HCV, including HIV and hepatitis $B$ virus (HBV), present a mounting concern, as DAA therapy does not prevent reinfection upon subsequent HCV exposure and does not offer treatment for HIV or HBV (Abutaleb and Sherman 2018; Mücke et al. 2018). More importantly, HCV clearance with DAA therapy, although efficient, enigmatically does not prevent "cured" liver from progressing to severe liver disease such as cirrhosis and/or liver cancer. In addition, liver-specific interventions to disrupt inflammasome activation and/or IL$1 \beta$ actions are needed for treatment of acute 
and chronic liver inflammatory disease linked with new or reacquisition of HCV infection, thus protecting the liver tissue from damage that could otherwise independently propagate hepatic inflammation. Moreover, it is not clear whether the diseased liver can fully repair itself once HCV is cured, nor is it known whether the hepatic inflammatory response has returned to homeostatic and normal levels present in healthy non-HCV liver. Long-term monitoring of patient liver status following HCV cure will ascertain whether the cure fully turns off the inflammatory response to return the diseased liver to a normal state. Finally, as noted above, DAA therapy can drive the outgrowth of drugresistant virus, although this is a very rare outcome (Bradshaw et al. 2019; Costa et al. 2019). DAA therapy is still not universally effective against all HCV genotypes (Hayes et al. 2019; Paolucci et al. 2019), and IFN therapy is variably used as the treatment for chronic HCV infection in countries outside of the United States and Western Europe (Esmat et al. 2014; Asselah and Bourlière 2015). Studies comparing DAAs and IFN in the treatment of HCV infection and reinfection should be considered to determine the best approach for therapy against difficult-to-treat $\mathrm{HCV}$. Understanding how to target and modulate innate immunity and the actions of IFN and ISGs remains essential for improving IFN therapy as adduct for treatment of HCV infection. Thus, improving both DAA therapy and IFN therapy will impart success against difficult-to-treat $\mathrm{HCV}$ cases and will support the use of IFN-based therapy across patient populations in which DAA therapy is not yet widely applied.

\section{REFERENCES}

${ }^{*}$ Reference is also in this collection.

Aarreberg LD, Wilkins C, Ramos HJ, Green R, Davis MA, Chow K, Gale M Jr. 2018. Interleukin-1 $\beta$ signaling in dendritic cells induces antiviral interferon responses. MBio 9: e00342-18. doi:10.1128/mBio.00342-18

Aarreberg LD, Esser-Nobis K, Driscoll C, Shuvarikov A, Roby JA, Gale M Jr. 2019. Interleukin-1 $\beta$ induces mtDNA release to activate innate immune signaling via cGASSTING. Mol Cell 74: 801-815.e6. doi:10.1016/j.molcel .2019 .02 .038
Abutaleb A, Sherman KE. 2018. A changing paradigm: management and treatment of the HCV/HIV-co-infected patient. Hepatol Int 12: 500-509. doi:10.1007/s12072-0189896-4

Aka PV, Kuniholm MH, Pfeiffer RM, Wang AS, Tang W, Chen S, Astemborski J, Plankey M, Villacres MC, Peters MG, et al. 2014. Association of the IFNL4- $\Delta$ G allele with impaired spontaneous clearance of hepatitis $C$ virus. $J$ Infect Dis 209: 350-354. doi:10.1093/infdis/jit433

Akira S, Uematsu S, Takeuchi O. 2006. Pathogen recognition and innate immunity. Cell 124: 783-801. doi:10.1016/j .cell.2006.02.015

Anderson JP, Mueller JL, Rosengren S, Boyle DL, Schaner P, Cannon SB, Goodyear CS, Hoffman HM. 2004. Structural, expression, and evolutionary analysis of mouse CIAS1. Gene 338: 25-34. doi:10.1016/j.gene.2004.05.002

Ank N, West H, Bartholdy C, Eriksson K, Thomsen AR, Paludan SR. 2006. Lambda interferon (IFN- $\lambda$ ), a type III IFN, is induced by viruses and IFNs and displays potent antiviral activity against select virus infections in vivo. J Virol 80: 4501-4509. doi:10.1128/JVI.80.9.45014509.2006

Ank N, Iversen MB, Bartholdy C, Staeheli P, Hartmann R, Jensen UB, Dagnaes-Hansen F, Thomsen AR, Chen Z, Haugen $\mathrm{H}$, et al. 2008. An important role for type III interferon (IFN- $\lambda /$ IL-28) in TLR-induced antiviral activity. J Immunol 180: 2474-2485. doi:10.4049/jimmunol .180 .4 .2474

Asselah T, Bourlière M. 2015. Hepatitis C virus: current and evolving treatments for genotype 4. Gastroenterol Clin North Am 44: 859-870. doi:10.1016/j.gtc.2015.07.013

Baranova A, Jarrar MH, Stepanova M, Johnson A, Rafiq N, Gramlich T, Chandhoke V, Younossi ZM. 2011. Association of serum adipocytokines with hepatic steatosis and fibrosis in patients with chronic hepatitis C. Digestion 83: 32-40. doi:10.1159/000314592

Bartenschlager R. 1999. The NS3/4A proteinase of the hepatitis $C$ virus: unravelling structure and function of an unusual enzyme and a prime target for antiviral therapy. J Viral Hepat 6: 165-181. doi:10.1046/j.1365-2893.1999 .00152.x

Bibert S, Roger T, Calandra T, Bochud M, Cerny A, Semmo N, Duong FH, Gerlach T, Malinverni R, Moradpour D, et al. 2013. IL28B expression depends on a novel TT/-G polymorphism which improves HCV clearance prediction. J Exp Med 210: 1109-1116. doi:10.1084/jem .20130012

Bortolami M, Kotsafti A, Cardin R, Farinati F. 2008. Fas/ FasL system, IL-1 $\beta$ expression and apoptosis in chronic HBV and HCV liver disease. J Viral Hepat 15: 515-522. doi:10.1111/j.1365-2893.2008.00974.x

Bradshaw D, Mbisa JL, Geretti AM, Healy BJ, Cooke GS, Foster GR, Thomson EC, McLauchlan J, Agarwal K, Sabin C, et al. 2019. Consensus recommendations for resistance testing in the management of chronic hepatitis $\mathrm{C}$ virus infection: public health england $\mathrm{HCV}$ resistance group. J Infect 79: 503-512. doi:10.1016/j.jinf.2019.10.007

Broggi A, Tan Y, Granucci F, Zanoni I. 2017. IFN- $\lambda$ suppresses intestinal inflammation by non-translational regulation of neutrophil function. Nat Immunol 18: 10841093. doi:10.1038/ni.3821 
J. Schwerk et al.

Burdette D, Haskett A, Presser L, McRae S, Iqbal J, Waris G. 2012. Hepatitis $C$ virus activates interleukin- $1 \beta$ via caspase-1-inflammasome complex. J Gen Virol 93: 235-246. doi:10.1099/vir.0.034033-0

Chattergoon MA, Levine JS, Latanich R, Osburn WO, Thomas DL, Cox AL. 2011. High plasma interleukin-18 levels mark the acute phase of hepatitis $\mathrm{C}$ virus infection. J Infect Dis 204: 1730-1740. doi:10.1093/infdis/jir642

Chattergoon MA, Latanich R, Quinn J, Winter ME, Buckheit RW, Blankson JN, Pardoll D, Cox AL. 2014. HIV and HCV activate the inflammasome in monocytes and macrophages via endosomal Toll-like receptors without induction of type 1 interferon. PLoS Pathog 10: e1004082. doi:10.1371/journal.ppat.1004082

Chow KT, Gale M Jr, Loo YM. 2018. RIG-I and other RNA sensors in antiviral immunity. Annu Rev Immunol 36: 667-694. doi:10.1146/annurev-immunol-042617-053309

Costa VD, Pellegrini P, Rotman V, Pittella AM, Nunes EP, Lago BV, Lampe E, Mello FCA. 2019. Resistance mutations $\mathrm{A} 30 \mathrm{~K}$ and $\mathrm{Y} 93 \mathrm{~N}$ associated with treatment failure with sofosbuvir and daclatasvir for hepatitis $\mathrm{C}$ virus infection non-responder patients: case reports. Viruses 11: 1004. doi:10.3390/v11111004

Csak T, Ganz M, Pespisa J, Kodys K, Dolganiuc A, Szabo G. 2011. Fatty acid and endotoxin activate inflammasomes in mouse hepatocytes that release danger signals to stimulate immune cells. Hepatology 54: 133-144. doi:10.1002/ hep. 24341

Davidson S, McCabe TM, Crotta S, Gad HH, Hessel EM, Beinke S, Hartmann R, Wack A. 2016. IFN $\lambda$ is a potent anti-influenza therapeutic without the inflammatory side effects of IFN $\alpha$ treatment. EMBO Mol Med 8: 1099-1112. doi:10.15252/emmm.201606413

Dinarello CA. 1999. IL-18: A TH1-inducing, proinflammatory cytokine and new member of the IL-1 family. $J$ Allergy Clin Immunol 103: 11-24. doi:10.1016/S00916749(99)70518-X

Dinarello CA. 2002. The IL-1 family and inflammatory diseases. Clin Exp Rheumatol 20: S1-13.

Di Paolo NC, Shayakhmetov DM. 2016. Interleukin $1 \alpha$ and the inflammatory process. Nat Immunol 17: 906-913. doi:10.1038/ni.3503

Dower SK, Kronheim SR, Hopp TP, Cantrell M, Deeley M, Gillis S, Henney CS, Urdal DL. 1986. The cell surface receptors for interleukin- $1 \alpha$ and interleukin- $1 \beta$ are identical. Nature 324: 266-268. doi:10.1038/324266a0

Dreux M, Garaigorta U, Boyd B, Décembre E, Chung J, Whitten-Bauer C, Wieland S, Chisari FV. 2012. Shortrange exosomal transfer of viral RNA from infected cells to plasmacytoid dendritic cells triggers innate immunity. Cell Host Microbe 12: 558-570. doi:10.1016/j.chom.2012 .08 .010

Dumoutier L, Tounsi A, Michiels T, Sommereyns C, Kotenko SV, Renauld JC. 2004. Role of the interleukin (IL)-28 receptor tyrosine residues for antiviral and antiproliferative activity of IL-29/interferon- $\lambda 1$ : similarities with type I interferon signaling. J Biol Chem 279: 32269-32274. doi:10.1074/jbc.M404789200

Elliott EI, Sutterwala FS. 2015. Initiation and perpetuation of NLRP3 inflammasome activation and assembly. Immunol Rev 265: 35-52. doi:10.1111/imr.12286
Esmat G, El Kassas M, Hassany M, Gamil M, El Raziky M. 2014. Optimizing treatment for HCV genotype 4: PEGIFN alfa $2 \mathrm{a}$ vs. PEG-IFN alfa $2 \mathrm{~b}$; the debate continues. Liver Int 34: 24-28. doi:10.1111/liv.12397

Farag NS, Breitinger U, El-Azizi M, Breitinger HG. 2017. The $\mathrm{p} 7$ viroporin of the hepatitis $\mathrm{C}$ virus contributes to liver inflammation by stimulating production of Interleukin-1ß. Biochim Biophys Acta 1863: 712-720. doi:10 .1016/j.bbadis.2016.12.006

Ferreon JC, Ferreon AC, Li K, Lemon SM. 2005. Molecular determinants of TRIF proteolysis mediated by the hepatitis C virus NS3/4A protease. J Biol Chem 280: 2048320492. doi:10.1074/jbc.M500422200

Forero A, Ozarkar S, Li H, Lee CH, Hemann EA, Nadjsombati MS, Hendricks MR, So L, Green R, Roy CN, et al. 2019. Differential activation of the transcription factor IRF1 underlies the distinct immune responses elicited by type I and type III interferons. Immunity 51: 451464.e6. doi:10.1016/j.immuni.2019.07.007

Foy E, Li K, Sumpter R Jr, Loo YM, Johnson CL, Wang C, Fish PM, Yoneyama M, Fujita T, Lemon SM, et al. 2005. Control of antiviral defenses through hepatitis $\mathrm{C}$ virus disruption of retinoic acid-inducible gene-I signaling. Proc Natl Acad Sci 102: 2986-2991. doi:10.1073/pnas .0408707102

Friebe P, Boudet J, Simorre JP, Bartenschlager R. 2005. Kissing-loop interaction in the $3^{\prime}$ end of the hepatitis $C$ virus genome essential for RNA replication. J Virol 79: 380 392. doi:10.1128/JVI.79.1.380-392.2005

Galani IE, Triantafyllia V, Eleminiadou EE, Koltsida O, Stavropoulos A, Manioudaki M, Thanos D, Doyle SE, Kotenko SV, Thanopoulou K, et al. 2017. Interferon- $\lambda$ mediates non-redundant front-line antiviral protection against influenza virus infection without compromising host fitness. Immunity 46: 875-890.e6. doi:10.1016/j .immuni.2017.04.025

Ge D, Fellay J, Thompson AJ, Simon JS, Shianna KV, Urban TJ, Heinzen EL, Qiu P, Bertelsen AH, Muir AJ, et al. 2009. Genetic variation in IL28B predicts hepatitis C treatment-induced viral clearance. Nature 461: 399-401. doi:10.1038/nature08309

* Gerold G, Moeller R, Pietschmann T. 2020. Hepatitis C virus entry: protein interactions and fusion determinants governing productive hepatocyte invasion. Cold Spring Harb Perspect Med 10: a036830. doi: 10.1101/cshperspect .a036830.

Hamming OJ, Terczyńska-Dyla E, Vieyres G, Dijkman R, Jørgensen SE, Akhtar H, Siupka P, Pietschmann T, Thiel V, Hartmann R. 2013. Interferon $\lambda 4$ signals via the IFN $\lambda$ receptor to regulate antiviral activity against $\mathrm{HCV}$ and coronaviruses. EMBO J 32: 3055-3065. doi:10.1038/em boj. 2013.232

Hayes CN, Imamura M, Chayama K. 2019. Management of HCV patients in cases of direct-acting antiviral failure. Expert Rev Gastroenterol Hepatol 13: 839-848. doi:10 $.1080 / 17474124.2019 .1651642$

Helbig KJ, Lau DT, Semendric L, Harley HA, Beard MR. 2005. Analysis of ISG expression in chronic hepatitis C identifies viperin as a potential antiviral effector. Hepatology 42: 702-710. doi:10.1002/hep.20844

Hemann EA, Green R, Turnbull JB, Langlois RA, Savan R, Gale M Jr. 2019. Interferon- $\lambda$ modulates dendritic cells to 
facilitate $\mathrm{T}$ cell immunity during infection with influenza A virus. Nat Immunol 20: 1035-1045. doi:10.1038/ s41590-019-0408-z

Hong M, Schwerk J, Lim C, Kell A, Jarret A, Pangallo J, Loo YM, Liu S, Hagedorn CH, Gale M Jr, et al. 2016. Interferon $\lambda 4$ expression is suppressed by the host during viral infection. J Exp Med 213: 2539-2552. doi:10.1084/jem .20160437

Ichinohe T, Lee HK, Ogura Y, Flavell R, Iwasaki A. 2009. Inflammasome recognition of influenza virus is essential for adaptive immune responses. J Exp Med 206: 79-87. doi:10.1084/jem.20081667

Isaacs A, Lindenmann J. 1957. Virus interference. I. The interferon. Proc R Soc Lond B Biol Sci 147: 258-267.

Ishii S, Koziel MJ. 2008. Immune responses during acute and chronic infection with hepatitis $\mathrm{C}$ virus. Clin Immunol 128: 133-147. doi:10.1016/j.clim.2008.03.525

Jarret A, McFarland AP, Horner SM, Kell A, Schwerk J, Hong M, Badil S, Joslyn RC, Baker DP, Carrington M, et al. 2016. Hepatitis-C-virus-induced microRNAs dampen interferon-mediated antiviral signaling. Nat Med 22: 1475-1481. doi:10.1038/nm.4211

Jilg N, Lin W, Hong J, Schaefer EA, Wolski D, Meixong J, Goto K, Brisac C, Chusri P, Fusco DN, et al. 2014. Kinetic differences in the induction of interferon stimulated genes by interferon- $\alpha$ and interleukin $28 \mathrm{~B}$ are altered by infection with hepatitis C virus. Hepatology 59: 1250-1261. doi:10.1002/hep.26653

Jin C, Flavell RA. 2010. Molecular mechanism of NLRP3 inflammasome activation. J Clin Immunol 30: 628-631. doi:10.1007/s10875-010-9440-3

Khatun M, Ray RB. 2019. Mechanisms underlying hepatitis C virus-associated hepatic fibrosis. Cells 8: 1249. doi:10 .3390/cells8101249

Kotenko SV, Gallagher G, Baurin VV, Lewis-Antes A, Shen M, Shah NK, Langer JA, Sheikh F, Dickensheets H, Donnelly RP. 2003. IFN- $\lambda s$ mediate antiviral protection through a distinct class II cytokine receptor complex. Nat Immunol 4: 69-77. doi:10.1038/ni875

Krenkel O, Tacke F. 2017. Liver macrophages in tissue homeostasis and disease. Nat Rev Immunol 17: 306-321. doi:10.1038/nri.2017.11

Kumar V, Abbas AK, Aster JC. 2013. Robbins basic pathology. Saunders, Philadelphia.

Lau DT, Fish PM, Sinha M, Owen DM, Lemon SM, Gale M Jr. 2008. Interferon regulatory factor-3 activation, hepatic interferon-stimulated gene expression, and immune cell infiltration in hepatitis $\mathrm{C}$ virus patients. Hepatology 47: 799-809. doi:10.1002/hep.22076

Lau DT, Negash A, Chen J, Crochet N, Sinha M, Zhang Y, Guedj J, Holder S, Saito T, Lemon SM, et al. 2013. Innate immune tolerance and the role of Kupffer cells in differential responses to interferon therapy among patients with HCV genotype 1 infection. Gastroenterology 144: 402-413.e12. doi:10.1053/j.gastro.2012.10.044

Lech M, Avila-Ferrufino A, Skuginna V, Susanti HE, Anders HJ. 2010. Quantitative expression of RIG-like helicase, NOD-like receptor and inflammasome-related mRNAs in humans and mice. Int Immunol 22: 717-728. doi:10 $.1093 /$ intimm/dxq058
Levitzki A, Gazit A, Osherov N, Posner I, Gilon C. 1991. Inhibition of protein-tyrosine kinases by tyrphostins. Methods Enzymol 201: 347-361. doi:10.1016/0076-6879 (91)01031-V

Li K, Foy E, Ferreon JC, Nakamura M, Ferreon AC, Ikeda M, Ray SC, Gale M Jr, Lemon SM. 2005. Immune evasion by hepatitis C virus NS3/4A protease-mediated cleavage of the Toll-like receptor 3 adaptor protein TRIF. Proc Natl Acad Sci 102: 2992-2997. doi:10.1073/pnas.0408824102

Li P, He K, Li J, Liu Z, Gong J. 2017. The role of Kupffer cells in hepatic diseases. Mol Immunol 85: 222-229. doi:10 .1016/j.molimm.2017.02.018

Liaskou E, Wilson DV, Oo YH. 2012. Innate immune cells in liver inflammation. Mediators Inflamm 2012: 949157. doi:10.1155/2012/949157

Lin J, Wu JF, Zhang Q, Zhang HW, Cao GW. 2014. Virusrelated liver cirrhosis: molecular basis and therapeutic options. World J Gastroenterol 20: 6457-6469. doi:10 .3748/wjg.v20.i21.6457

Longatti A, Boyd B, Chisari FV. 2015. Virion-independent transfer of replication-competent hepatitis $C$ virus RNA between permissive cells. J Virol 89: 2956-2961. doi:10 1128/JVI.02721-14

Loo YM, Owen DM, Li K, Erickson AK, Johnson CL, Fish PM, Carney DS, Wang T, Ishida $\mathrm{H}$, Yoneyama $\mathrm{M}$, et al. 2006. Viral and therapeutic control of IFN- $\beta$ promoter stimulator 1 during hepatitis $\mathrm{C}$ virus infection. Proc Natl Acad Sci 103: 6001-6006. doi:10.1073/pnas.0601523103

Lu YF, Goldstein DB, Urban TJ, Bradrick SS. 2015a. Interferon- $\lambda 4$ is a cell-autonomous type III interferon associated with pre-treatment hepatitis C virus burden. Virology 476: 334-340. doi:10.1016/j.virol.2014.12.020

Lu YF, Mauge DM, Goldstein DB, Urban TJ, Weeks KM, Bradrick SS. 2015b. IFNL3 mRNA structure is remodeled by a functional non-coding polymorphism associated with hepatitis C virus clearance. Sci Rep 5: 16037. doi:10 .1038/srep16037

Marcello T, Grakoui A, Barba-Spaeth G, Machlin ES, Kotenko SV, MacDonald MR, Rice CM. 2006. Interferons $\alpha$ and $\lambda$ inhibit hepatitis $C$ virus replication with distinct signal transduction and gene regulation kinetics. Gastroenterology 131: 1887-1898. doi:10.1053/j.gastro.2006.09 .052

Martinon F, Burns K, Tschopp J. 2002. The inflammasome: a molecular platform triggering activation of inflammatory caspases and processing of proIL- $\beta$. Mol Cell 10: 417-426. doi:10.1016/S1097-2765(02)00599-3

Masumoto J, Taniguchi S, Nakayama J, Shiohara M, Hidaka E, Katsuyama T, Murase S, Sagara J. 2001. Expression of apoptosis-associated speck-like protein containing a caspase recruitment domain, a pyrin $\mathrm{N}$-terminal homology domain-containing protein, in normal human tissues. J Histochem Cytochem 49: 1269-1275. doi:10 $1177 / 002215540104901009$

McFarland AP, Horner SM, Jarret A, Joslyn RC, Bindewald E, Shapiro BA, Delker DA, Hagedorn CH, Carrington M, Gale M Jr, et al. 2014. The favorable IFNL3 genotype escapes mRNA decay mediated by AU-rich elements and hepatitis $\mathrm{C}$ virus-induced microRNAs. Nat Immunol 15: 72-79. doi:10.1038/ni.2758

Meissner EG, Bon D, Prokunina-Olsson L, Tang W, Masur H, O’Brien TR, Herrmann E, Kottilil S, Osinusi A. 2014. 
J. Schwerk et al.

IFNL4- $\Delta$ G genotype is associated with slower viral clear ance in hepatitis C, genotype-1 patients treated with sofosbuvir and ribavirin. J Infect Dis 209: 1700-1704. doi:10 .1093/infdis/jit827

Metz P, Reuter A, Bender S, Bartenschlager R. 2013. Interferon-stimulated genes and their role in controlling hepatitis C virus. J Hepatol 59: 1331-1341. doi:10.1016/j.jhep .2013 .07 .033

Molyvdas A, Georgopoulou U, Lazaridis N, Hytiroglou P, Dimitriadis A, Foka P, Vassiliadis T, Loli G, Phillipidis A, Zebekakis P, et al. 2018. The role of the NLRP3 inflammasome and the activation of IL- $1 \beta$ in the pathogenesis of chronic viral hepatic inflammation. Cytokine 110: 389396. doi:10.1016/j.cyto.2018.04.032

Mücke MM, Backus LI, Mücke VT, Coppola N, Preda CM, Yeh ML, Tang LSY, Belperio PS, Wilson EM, Yu ML, et al. 2018. Hepatitis B virus reactivation during direct-acting antiviral therapy for hepatitis C: a systematic review and meta-analysis. Lancet Gastroenterol Hepatol 3: 172-180. doi:10.1016/S2468-1253(18)30002-5

Negash AA, Gale M. 2015. Hepatitis regulation by the inflammasome signaling pathway. Immunol Rev 265: 143 155. doi:10.1111/imr.12279

Negash AA, Ramos HJ, Crochet N, Lau DT, Doehle B, Papic N, Delker DA, Jo J, Bertoletti A, Hagedorn CH, et al. 2013. IL- $1 \beta$ production through the NLRP3 inflammasome by hepatic macrophages links hepatitis $\mathrm{C}$ virus infection with liver inflammation and disease. PLoS Pathog 9: e1003330. doi:10.1371/journal.ppat.1003330

Negash AA, Olson RM, Griffin S, Gale M. 2019. Modulation of calcium signaling pathway by hepatitis $\mathrm{C}$ virus core protein stimulates NLRP3 inflammasome activation. PLoS Pathog 15: e1007593. doi:10.1371/journal.ppat .1007593

O’Brien TR, Pfeiffer RM, Paquin A, Lang Kuhs KA, Chen S, Bonkovsky HL, Edlin BR, Howell CD, Kirk GD, Kuniholm MH, et al. 2015. Comparison of functional variants in IFNL4 and IFNL3 for association with HCV clearance. J Hepatol 63: 1103-1110. doi:10.1016/j.jhep.2015.06.035

Paolucci S, Novazzi F, Piralla A, Maserati R, Gulminetti R, Novati S, Barbarini G, Sacchi P, Fratini A, Bellotti L, et al. 2019. Viral dynamics among HCV infected patients with different genotypes treated with genotypic specific or pan-genotypic direct-acting antiviral agent combinations. Infect Drug Resist 12: 1975-1984. doi:10.2147/ IDR.S205282

Park SH, Rehermann B. 2014. Immune responses to HCV and other hepatitis viruses. Immunity 40: 13-24. doi:10 .1016/j.immuni.2013.12.010

Peiffer KH, Sommer L, Susser S, Vermehren J, Herrmann E, Doring M, Dietz J, Perner D, Berkowski C, Zeuzem S, et al. 2016. Interferon $\lambda 4$ genotypes and resistance-associated variants in patients infected with hepatitis $\mathrm{C}$ virus genotypes 1 and 3. Hepatology 63: 63-73. doi:10.1002/ hep. 28255

Prokunina-Olsson L, Muchmore B, Tang W, Pfeiffer RM, Park H, Dickensheets H, Hergott D, Porter-Gill P, Mumy A, Kohaar I, et al. 2013. A variant upstream of IFNL3 (IL28B) creating a new interferon gene IFNL4 is associated with impaired clearance of hepatitis C virus. Nat Genet 45: 164-171. doi:10.1038/ng.2521
Rajan JV, Rodriguez D, Miao EA, Aderem A. 2011. The NLRP3 inflammasome detects encephalomyocarditis virus and vesicular stomatitis virus infection. $J$ Virol 85: 4167-4172. doi:10.1128/JVI.01687-10

Ramos HJ, Lanteri MC, Blahnik G, Negash A, Suthar MS, Brassil MM, Sodhi K, Treuting PM, Busch MP, Norris PJ et al. 2012. IL-1 $\beta$ signaling promotes CNS-intrinsic immune control of West Nile Virus infection. PLoS Pathog 8: e1003039. doi:10.1371/journal.ppat.1003039

Rauch A, Kutalik Z, Descombes P, Cai T, Di Iulio J, Mueller T, Bochud M, Battegay M, Bernasconi E, Borovicka J, et al. 2010. Genetic variation in IL28B is associated with chronic hepatitis $\mathrm{C}$ and treatment failure: A genome-wide association study. Gastroenterology 138: 1338-1345, 1345 e1331-1337. doi:10.1053/j.gastro.2009.12.056

Saito T, Owen DM, Jiang F, Marcotrigiano J, Gale M Jr. 2008. Innate immunity induced by composition-dependent RIG-I recognition of hepatitis C virus RNA. Nature 454: 523-527. doi:10.1038/nature07106

Sandmann L, Schulte B, Manns MP, Maasoumy B. 2019. Treatment of chronic hepatitis C: Efficacy, side effects and complications. Visc Med 35: 161-170. doi:10.1159/ 000500963

Schnell G, Loo YM, Marcotrigiano J, Gale M Jr. 2012. Uridine composition of the poly-U/UC tract of HCV RNA defines non-self recognition by RIG-I. PLoS Pathog 8: e1002839. doi:10.1371/journal.ppat.1002839

Schoggins JW. 2019. Interferon-stimulated genes: what do they all do? Annu Rev Virol 6: 567-584. doi:10.1146/an nurev-virology-092818-015756

Schoggins JW, Wilson SJ, Panis M, Murphy MY, Jones CT, Bieniasz P, Rice CM. 2011. A diverse range of gene products are effectors of the type I interferon antiviral response. Nature 472: 481-485. doi:10.1038/nature09907

Sheppard P, Kindsvogel W, Xu W, Henderson K, Schlutsmeyer S, Whitmore TE, Kuestner R, Garrigues U, Birks C, Roraback J, et al. 2003. IL-28, IL-29 and their class II cytokine receptor IL-28R. Nat Immunol 4: 63-68. doi:10.1038/ni873

Shrivastava S, Mukherjee A, Ray R, Ray RB. 2013. Hepatitis $\mathrm{C}$ virus induces interleukin-1 $\beta$ (IL-1 $\beta$ )/IL-18 in circulatory and resident liver macrophages. J Virol 87: 1228412290. doi:10.1128/JVI.01962-13

Sims JE, Acres RB, Grubin CE, McMahan CJ, Wignall JM, March CJ, Dower SK. 1989. Cloning the interleukin 1 receptor from human T cells. Proc Natl Acad Sci 86: 8946-8950. doi:10.1073/pnas.86.22.8946

Smolders EJ, Jansen AME, Ter Horst PGJ, Rockstroh J, Back DJ, Burger DM. 2019. Viral hepatitis C therapy: pharmacokinetic and pharmacodynamic considerations: A 2019 update. Clin Pharmacokinet 58: 1237-1263. doi:10.1007/ s40262-019-00774-0

Sommereyns C, Paul S, Staeheli P, Michiels T. 2008. IFNlambda (IFN- $\lambda$ ) is expressed in a tissue-dependent fashion and primarily acts on epithelial cells in vivo. PLoS Pathog 4: e1000017. doi:10.1371/journal.ppat.1000017

Streicher F, Jouvenet N. 2019. Stimulation of innate immunity by host and viral RNAs. Trends Immunol 40: 11341148. doi:10.1016/j.it.2019.10.009

Sumpter R Jr, Loo YM, Foy E, Li K, Yoneyama M, Fujita T, Lemon SM, Gale M Jr. 2005. Regulating intracellular antiviral defense and permissiveness to hepatitis $\mathrm{C}$ virus 
RNA replication through a cellular RNA helicase, RIG-I. $J$ Virol 79: 2689-2699. doi:10.1128/JVI.79.5.2689-2699 .2005

Suppiah V, Moldovan M, Ahlenstiel G, Berg T, Weltman M, Abate ML, Bassendine M, Spengler U, Dore GJ, Powell E, et al. 2009. IL28B is associated with response to chronic hepatitis $\mathrm{C}$ interferon- $\alpha$ and ribavirin therapy. Nat Genet 41: 1100-1104. doi:10.1038/ng.447

* Tabata K, Neufeldt CJ, Bartenschlager R. 2020. Hepatitis C virus replication. Cold Spring Harb Perspect Med 10: a037093. doi: 10.1101/cshperspect.a037093.

Tanaka Y, Furuta T, Suzuki S, Orito E, Yeo AE, Hirashima N, Sugauchi F, Ueda R, Mizokami M. 2003. Impact of interleukin-1 $\beta$ genetic polymorphisms on the development of hepatitis C virus-related hepatocellular carcinoma in Japan. J Infect Dis 187: 1822-1825. doi:10.1086/375248

Tanaka Y, Nishida N, Sugiyama M, Kurosaki M, Matsuura K, Sakamoto N, Nakagawa M, Korenaga M, Hino K, Hige S, et al. 2009. Genome-wide association of IL28B with response to pegylated interferon- $\alpha$ and ribavirin therapy for chronic hepatitis C. Nat Genet 41: 1105-1109. doi:10 $.1038 /$ ng.449

Terczynska-Dyla E, Bibert S, Duong FH, Krol I, Jorgensen S, Collinet E, Kutalik Z, Aubert V, Cerny A, Kaiser L, et al. 2014. Reduced IFN $\lambda 4$ activity is associated with improved $\mathrm{HCV}$ clearance and reduced expression of interferonstimulated genes. Nat Commun 5: 5699. doi:10.1038/ ncomms6699

Thomas DL, Thio CL, Martin MP, Qi Y, Ge D, O'Huigin C Kidd J, Kidd K, Khakoo SI, Alexander G, et al. 2009. Genetic variation in IL28B and spontaneous clearance of hepatitis C virus. Nature 461: 798-801. doi:10.1038/ nature08463

Thompson MR, Kaminski JJ, Kurt-Jones EA, Fitzgerald KA. 2011. Pattern recognition receptors and the innate immune response to viral infection. Viruses 3: 920-940. doi:10.3390/v3060920

Tilg H, Wilmer A, Vogel W, Herold M, Nölchen B, Judmaier G, Huber C. 1992. Serum levels of cytokines in chronic liver diseases. Gastroenterology 103: 264-274. doi:10 .1016/0016-5085(92)91122-K

Vecchiet J, Falasca K, Cacciatore P, Zingariello P, Dalessandro M, Marinopiccoli M, D’Amico E, Palazzi C, Petrarca C, Conti P, et al. 2005. Association between plasma interleukin-18 levels and liver injury in chronic hepatitis C virus infection and non-alcoholic fatty liver disease. Ann Clin Lab Sci 35: 415-422.

Wang Y, Kato N, Hoshida Y, Yoshida H, Taniguchi H, Goto T, Moriyama M, Otsuka M, Shiina S, Shiratori Y, et al. 2003. Interleukin-1 $\beta$ gene polymorphisms associated with hepatocellular carcinoma in hepatitis $C$ virus infection. Hepatology 37: 65-71. doi:10.1053/jhep.2003.50017

Wang N, Liang Y, Devaraj S, Wang J, Lemon SM, Li K. 2009. Toll-like receptor 3 mediates establishment of an antiviral state against hepatitis C virus in hepatoma cells. J Virol 83: 9824-9834. doi:10.1128/JVI.01125-09

Wang CC, Cheng PN, Kao JH. 2020. Systematic review: chronic viral hepatitis and metabolic derangement. Aliment Pharmacol Ther 51: 216-230. doi:10.1111/apt .15575

Watanabe A, Sohail MA, Gomes DA, Hashmi A, Nagata J, Sutterwala FS, Mahmood S, Jhandier MN, Shi Y, Flavell RA, et al. 2009. Inflammasome-mediated regulation of hepatic stellate cells. Am J Physiol Gastrointest Liver Physiol 296: G1248-G1257. doi:10.1152/ajpgi.90223.2008

Wilkins C, Woodward J, Lau DT, Barnes A, Joyce M, McFarlane N, McKeating JA, Tyrrell DL, Gale M Jr. 2013. IFITM1 is a tight junction protein that inhibits hepatitis C virus entry. Hepatology 57: 461-469. doi:10.1002/hep .26066

Wu J, Zhou Y, Fu X, Deng M, Zheng Y, Tian G, Li Y, Wang C, Ding C, Ruan B, et al. 2019. The burden of chronic hepatitis C in China from 2004 to 2050: An individual-based modeling study. Hepatology 69: 1442-1452. doi:10.1002/ hep. 30476

Yoneyama M, Kikuchi M, Natsukawa T, Shinobu N, Imaizumi T, Miyagishi M, Taira K, Akira S, Fujita T. 2004. The RNA helicase RIG-I has an essential function in doublestranded RNA-induced innate antiviral responses. Nat Immunol 5: 730-737. doi:10.1038/ni1087

Zeisel MB, Dhawan P, Baumert TF. 2018. Tight junction proteins in gastrointestinal and liver disease. Gut doi:10 .1136/gutjnl-2018-316906

Zhou Z, Hamming OJ, Ank N, Paludan SR, Nielsen AL, Hartmann R. 2007. Type III interferon (IFN) induces a type I IFN-like response in a restricted subset of cells through signaling pathways involving both the JakSTAT pathway and the mitogen-activated protein kinases. J Virol 81: 7749-7758. doi:10.1128/JVI.02438-06 